\title{
Eksistensi Pabbagang Ponrang Kabupaten Luwu 1970-2016
}

\author{
Tantri Wulandari, M. Rasyid Ridha, Najamuddin \\ Pendidikan Sejarah FIS UNM \\ Tantriwul15@gmail.com
}

\begin{abstract}
Abstrak
Tulisan ini mengkaji tentang eksistensi Pabbagang Di Desa Ponrang Kecamatan Ponrang Kabupaten Luwu ( 1970-2016). Hasil penelitian ini tentang Pabbagang di Desa Ponrang pada masa era tradisonal dan, era modern dan kehidupan sosial ekonomi maupun system bagi hasil. awal mula keberadaan pabbagang di Desa Ponrang karena alat tangkap ikan yang digunakan mulai menggunakan bagang dan adapun yang pertama kali yang memiliki bagang d Desa Ponrang adalah Ambeambarang, dan membahas kinerja pabbagang tradisional dengan kinerja pabbagang modern serta bagaimana system bagi hasil antara si pemilik modal atau pemilik bagang di setiap era dengan pabbagang itu sendiri dimana system bagi hasil yang di terapkan adalah system tesan, dan persaingan antara pabbagang tradisional dengan pabbagang modern dimana hasil tangkapan pabbagang tradisional hanya sedikit dan dengan jenis ikan yang tidak bervariasi sedangka pabbagang moderen hasil tangkapanya lebih banyak dengan jenis ikan yang bervariasi , dan system kerja yang di laukan oleh para pabbagang ketika di bagang dimana ketika mencari ikan menggunakan bagang tradisional semua tanpa bantuan mesin sedangkan ketika menggunakan bagang moderen sudah memakai mesin. Alat tangkap ikan yang menjadi alat tangkap utama yang digunakan oleh nelayan Desa Ponrang yaitu Bagang, dimana pada era Tradisional nelayan menggunakan bagang tancap sedangkan pada era moderen menggunakan bagang gerak yang biasanya masyarakat Desa Ponrang menyebutnya Bagang Rambo. Penelitian ini bersifat Deskriptif analisis dengan menggunakan metode historis, melalui tahapan tahapan kerja yang meliputi ; Heusristik, kritik interprestasi dan Histriografi dan adapun beberapa masyarakat di Desa Ponrang yang diwawancarai antara lain Hj.Suhara, Syamsuddin, Hj.Marzuki, Saenal, dan Mancu . Konsep Ilmu Sosial Seperti melihat kondisi masyarakat di Desa Ponrang untuk menganalisis masalah yang relevan, terutama dalam mengkaji kehidupan sosial dan ekonomi berkaitan dengan perubahan kehidupan sosial pada masyarakat nelayan.
\end{abstract}

\section{Kata Kunci: Nelayan, Bagang, Desa Ponrang}

\begin{abstract}
This paper examines the existence Pabbagang In the village of the District Ponrang Ponrang Luwu Regency (1970-2016). The results of this study on Ponrang Pabbagang in the village at the time and the traditional era, the modern age and socio-economic life and system for the results. This research shows the beginning where pabbagang Village Ponrang, the origin of the naming Pabbagang and discuss the performance of pabbagang traditional performance pabbagang modern as well as how the system of revenue sharing between the owners of capital or owner bagang in every era with pabbagang itself where the system for the results in applied is tesan system, and how the competition between traditional pabbagang with modern pabbagang, and work system in laukan by pabbagang when in the butterflyfish (marine). The main fishing gear being the principal
\end{abstract}


fishing gear used by the fishing village of Ponrang namely Bagang, where in the era of traditional fishermen using bagang step while in the modern era using motion bagang Ponrang village in which the people call Bagang Rambo. and the village social system Pabbagang Ponrang influenced by everyday life of fishermen at the time of the search process fish, In the 1980s Ponrang Pabbagang society has entered the modern era where fishermen are already using modern fishing gear as well. since the social and economic life has improved, and the result of it is also the case that fundamental changes in lifestyle Ponrang village society especially those who cultivate the profession as a fisherman pabbagang or in terms of economic level of society. and the village social system Pabbagang Ponrang influenced by everyday life of fishermen at the time of the search process fish, In the 1980s Ponrang Pabbagang society has entered the modern era where fishermen are already using modern fishing gear as well. since the social and economic life has improved, and the result of it is also the case that fundamental changes in lifestyle Ponrang village society especially those who cultivate the profession as a fisherman pabbagang or in terms of economic level of society. and the village social system Pabbagang Ponrang influenced by everyday life of fishermen at the time of the search process fish, In the 1980s Ponrang Pabbagang society has entered the modern era where fishermen are already using modern fishing gear as well. since the social and economic life has improved, and the result of it is also the case that fundamental changes in lifestyle Ponrang village society especially those who cultivate the profession as a fisherman pabbagang or in terms of economic level of society. This research is descriptive analysis using historical methods, through the stages of the stages of work which includes; Heusristik, interpretation and Histriografi criticism. As the concept of Social Sciences sociology used to analyze the relevant issues, particularly in assessing the socio-economic life associated with changes in social life in fishing communities

\section{Keyword : Fishermen, Bagang, Village Ponrang}

\section{A. Pendahuluan}

Menurut KBBI Eksistensi adalah berasal dari bahasa latin existere yang artinya muncul, ada, timbul memiliki keberadaan aktual.

Nelayan adalah mereka yang segalah aktivitasnya berkaitan dengan lingkungan laut dan pesisir. Atau mereka yang menjadikan sebagai mata pencaharian merekameskipun nelayan merupakan pekerjaan berat namun pada umumnya memiliki keterampilan sederhana

Nelayan merupakan istilah bagii orang yang sehari-hari bekerja menangkap ikan atau biota lainya yang hidup didasar maupun permukaan perairan yang menjadi daerah aktivitas nelayan ini dapat merupakan perairan tawar, payau maupun laut.
Pabbagang di Desa adalah sebutan lain dari Nelayan ,adapun alasan mengapa Nelayan di Desa Ponrang dikatakan Pabbagang dikarenakan alat Tangkap Nelayan di Desa Ponrang menggunakan Bagang sehingga nelayan di Desa Ponrang dikatakan Pabbagang.

Dengan demikian Eksistensi Pabbagang di Desa Ponrang ketika awal kemunculan Pabbagang itu sendiri masih bertahan sampai sekarang. meski di Desa Ponrang sendiri bukan hanya pabbagang salah satu nelayan di tetapi ada juga di namakan Pappuka tetapi Eksistensi Pabbagang di Desa Ponrang lebih maju dari segi populitas bahkan dari hasil penangkapanya.

Lokasi penelitian ini bukan merupakan daerah pesisir namun hal ini yang menjadi daya tarik dari penelitian ini salah satunya di Desa Ponrang sendiri bukan daerah 
pesisir namun rata-rata penduduk Desa Ponrang menggeluti profesi sebagai Pabbagang (Nelayan).

Lokasi penelitian kali ini yaitu di Desa Ponrang yang berada di Kecamatan Ponrang memiliki jumlah penduduk ratarata menggeluti profesi sebagai nelayan, tetapi lokasi desa ponrang tersebut bukan merupakan lokasi yang bermukim di daerah pesisir, menurut data yang di dapat dan melihat langsung lokasi penelitian di Desa Ponrang memiliki sungai yang terhubung dengan laut dan sungai ini menjadi jalur masyarkat pabbagang Ponrang ke laut untuk mencari ikan.

Kecamatan Ponrang merupakan salah satu daerah yang mempunyai 8 Desa diantaranya merupakan Desa Ponrang yang memiliki jarak yang di tempuh untuk menuju Ibu Kota Kecamatan 5 KM sedangkan jarak menujuh ke Ibu Kota Kabupaten kurang lebih 28 KM. Adapun Luas Desa Ponrang yakni kurang lebih 1.323 yang dibatasi oleh sebelah utara desa Mario, sebelah Timur teluk bone, sebelah selatan desa lumi dan desa lara. (BPS, 2016)

Berbeda dengan Desa Srigading Kecamatan Sanden Kabupaten Bantu dimana Kecamatan sanden yang terletak didaera pesisir pantai yang berahadapan semudra Indonesia dengan Jumlah penduduk berdasarkan BPS tahun 2005 , tercatat sebanyak 10.058 jiwa. Dan diihat dari serivikasi jenis profesi pekerjaan sebagai petani sedangkan profesi sebagai nelayan hanya sebagai pekerjaan . (Agusabdurrahman, 2008)

Usaha pemotoran (motorisasi) dan pemesinan alat tangkap (mekanisme) penangkapan ikan di Indonesia, pada umumnya mulai di terapkan sejak tahun 1970-an. (Ahmadin, 2009).

Pada tahun 1970-an pabbagang Ponrang telah mengalami moderisasi sedangkan pada tahun 2001 barulah masuk pada zaman moderen. Dimana pada tahun 1970 masih mnggunakan bagang tancap sedangkan tahun 2001 bagang yang di gunakan bagang rambo.

\section{B. Pembahasan}

\section{Awal Mula Pabbagang di Desa Ponrang}

Desa Ponrang merupakan desa yang berada di Kecamatan Ponrang yang memiliki penduduk rata-rata menggeluti profesi sebagai nelayan, adapun asal usul pabbagang di Desa Ponrang menurut informasi yang di peroleh tidak di ketahui pada tahun berapa pabbagang di Desa Ponrang muncul, namun adapun faktor utama yang mendorong masyarakat desa ponrang menggeluti profesi sebagai nelayan yaitu faktor kemiskinan kurangnya lapangan kerja pada masa itu membuat masyarakat desa ponrang menggeluti profesi sebagai pada masa itu. (Hj.Suhara, 2018)

Masyarakat di Desa Ponrang yang menggeluti profesi sebagai nelayan dinamakan Pabbagang dan adapun alasan mengapa nelayan Desa Ponrang dinamakan pabbagang karena alat tangkap yang digunakan untuk mencari ikan adalah Bagang dimana macam-macam bagang ada bagang tancap, bagang apung, dan bagang rambo. (Suhara, 2018).

Ambe ambarang merupakan orang yang pertama kali yang memiliki bagang di Desa Ponrang pada tahun 1960an, awalnya ambeambarang hanya wirausaha, dan sewaktu Ambeambarang berkunjung dirumah keluarga di Desa balambang dan Desa Karo, dimana secara kebutalan keluarga Ambe ambarang memiliki bagang tancap, Ambe ambarang kemudian berfikir untuk mendirikan bagang tancap karena kebutuhan masyarakat atas lauk sehari-hari terutama ikan sangat banyak dan di karena bukan hanya masyarakat di Desa Ponrang yang datang ke Ponrang ingin beli ikan tetapi masyarakat dari Desa tetangga banyak juga yang datang, kemudian Ambeambarang sewaktu itu membuat bagang tancap di daerah laut dekat dari Desa Labembe namun Ambe ambarang sendiri petama 
memiliki bagang ambe ambarang ikut pergi Mabbagang dan mengajak saudaranya, ambe ambarang mengembangkan usahanya dengan membeli bagang tancap lagi tancap dan keluarga dari ambe ambarang yang lain ikut membuat bagang tancap dan sampe sekarang banyak orang disini Desa Ponrang memiliki bagang yang memiliki modal dan yang memiliki bagang moderen pertama kalinya adalah Hj.Marsuki pada tahun 2001 (Suhara, 2018)

Menurut keterangan narasumber yang di dapatkan dari hasil wawancara yang memiliki bagang pertama kalinya Ambe ambara, namun ambeambarang telah meninggal Dunia sekarang usaha bagang Ambe ambarang di teruskan oleh anaknya yang bernama $\mathrm{Hj}$. Suhara dan suaminya surateng, dimana bapak dari $\mathrm{Hj}$. Suhara yaitu Ambeambarang sudah memiliki bagang pada tahun 1960an, awalnya Ambe ambarang ini hanya wirausaha iya mempunyai ide untuk membuat bagang ketika Ambe ambarang berkunjung di rumah salah satu kerabatnya di Desa Balambang dan Desa Karo yang sudah lebih dulu memiliki bagang dan disnilah awal munculnya bagang karena Ambe ambarang pada saat itu juga berfikir kebutuhan masyarakat Desa Ponrang bahkan dari desa tetangga lain memerlukan yang setiap paginya datang kepelabuhan Desa Ponrang untuk mencari ikan di Desa Ponrang

Ambeambarang sudah memiliki bagang 3 unit pada tahun 1980an dan memiliki bagang Rambo pada tahun 2002 dan di teruskan oleh anaknya yaitu $\mathrm{Hj}$.Suhara dan Surateng tetapi sudah banyak masyarakat ponrang yang memiliki modal kemudian mendirikan bagang sehingga sudah banyak masyarakat Desa Ponrang yang pergi mencari ikan dengan bekerja ke pemilik Bagang (Hj.Suhara, 2018)

Sedangkan yang memiliki bagang rambo pertama kalinya di Desa Ponrang adalah Hj.Marsuki pada tahun 2001 (Marsuki, 2018)
Jadi Pabbagang di Desa Ponrang ada ketika alat tangkap bagang yang di perkenalkan pertama kali oleh ambe ambarang ke masyarakat Desa Ponrang dimana ambeambarang mulai berfikir untuk menggunkan alat tangkap ikan bagang dikarenakan beberapa faktor salah satunya adalah kebutuhan ikan oleh masyarakat Desa Ponrang dan ini juga menjadi pemicu masyarakat lain untuk memiliki Bagang terutama yang memiliki modal usaha membuat atau membeli bagang.

\section{Proses Kegiatan Penangkapan Ikan}

a. Penangkapan Ikan Pada Era Tradisional

Nelayan Tradisonal yang termasuk sebagai masyarakat yang masuk dalam goongan miskin dengan rendahnya kulitas pangan dan pangan yang dikonsumsi, serta rendahnya taraf hidup. Di karenakan peralatan yang kurang memadai dalam usaha penangkapan ikan pada era tradisonal yang dilakukan oleh pabbagang Desa Ponrang.

Nelayan tradisional selalu menjaga keselarasan hubungan dengan alam (lingkungan). Karena itu, tidak heran jika dalam kegiatan menangkap ikan prosesnya selalu dilengkapi oleh unsur megic dengan sejumah simbol yang menyertainya. Sebelum melaut para nelayan di anjurkan secara kultur untuk melakukan atau memperhatikan beberapa pengamatan terhadap simbol tertentu alam dengan pertimbangan bahwa demi keselamatan diri serta untuk memprediksi ada atau tidaknya hasil tangkapan yang akan diperoleh. Hal ini juga sama yang diakukan oleh pabbagang desa ponrang pada masa tradisional mereka ketika ingin turun ke laut untuk mencari ikan maka mereka terlebih dulu melihat kondisi alam apakah mereka bisa turun untuk mencari ikan ke laut atau tidak.

Sebelum perkembangnya teknologi moderisasi terhadap alat penangkapan ikan di Desa Ponrang mereka terlebih dahulu mengenal alat tradisonal yang di gunakan untuk proses penangkapan ikan. Adapun 
alat tangkap ikan yang di gunakan oleh pabbagang di desa ponrang pada tahun 1970an yaitu koli, jaring atau jala, lampu yang menyala menggunakan minyak tanah, senter, bagang tancap dan bagang apung.

Berdasarkan informasi diperoleh pabbagang yang bermukim di Desa Ponrang dalam usaha mencari ikan yang menggunakan Alat tangkap tradisional di pakai oleh pabbagang Desa Ponrang pada tahun 1970an adalah bagang tancap dan bagang apung.

Bagang tancap dibangun tidak jauh dari garis pantai atau tempat yang tidak terlalu dalam .Hal ini dikarenakan alat yang digunakan berbahan baku bambu yang tentu ukurannya tidak begitu panjang, kadang disesuaikan dengan besar dari bambu yang digunakan. (Syamsu Bahri, 2014)

Tetapi jenis bagang yang digunakan oleh pabbagang desa ponrang ada juga yang terbuat dari kayu dari pohon kelapa Pada bagian tengah bagang tancap biasa terdapat rumah yang kecil yang dibuat yang dasar lantainya dan beratapkan daun sagu berfungsi sebagai tempat beristirahat para pabbagang yang telah melakukan aktivitasnya sebagai nelayan.

Pabbagang di desa ponrang sebelum sekarang menggunakan alat moderisasi, menggunakan bagang tancap, dimana bagang tancap itu sendiri berada di kedalaman yang cukup rendah dan ukurannya juga tidak terlalu besar dan setiap bagang tancap biasa hanya memuat 5 orang saja dari 5 orang tersebut mempunyai 1 pawang 4 anggota pabbagang pada tahun itu memulai aktivitasnya pada pagi buta, pukul 03.00 dikarenakan perahu yang digunakan belum mnggunakan motorisasi sehinggah perjalanan menuju lokasi memakan waktu 5-7jam dan pabbagang tinggal dilaut kadang 1 malam . (Pida, 2018)

Berdasarkan Keterangan tersebut dapat diperoleh bahwa pabbagang Desa Ponrang melakukan aktifitas sebagai pabbagang di mulai pada sore hari pukul 03.00 sore menuju lokasi penangkapan ikan dan biasanya pabbagang hanya bermalam 1 malam dan kembali ke rumah pada pukul 03.00 subuh, dalam beberapa hari untuk panen, Pabbang Desa Ponrang melakukan persiapan sebelum ke lokasi penangkapan terlebih dahulu dan mengecek perahu yang akan digunakan sembari mempersiapkan alat lainya seperti jala atau jaring, dan alat penerang, pengoprasian bagang yang dilakukan oleh pabbagang dilakukan pada malam hari. Seperti menurunkan jaring, dan menarik kembali jaring yang sudah terisi ikan dan proses pengoprasian ini sendiri dilakukan secara manual tanpa lat bantu dari mesin dan ini dilakukan pabbagang bersama-sama dan adapun jenis ikan yang biasanya didapatkan adalah ikan layang dan ikan mairo dan ikan malaja dan hasil tangkapan pabbagang di bawah pulang ke pelabuhan Desa Ponrang untuk dijual oleh para paccata atau pemilik bagang.

Selain bagang tancap masyarakat Desa Ponrang pada tahun 1970an sudah banyak menggunakan bagang apung, keberadaan bagang apung dalam lingkup kehidupan pabbagang di Desa Ponrang menganggap bagang ini merupakan pengembangan dari bagang tancap dan sama seperti bagang tancap bagang apung ini lokasinya tidak jauh dari pantai atau tempat yang dangkal dan tidak bergerak

\section{b. Penangkapan Ikan Pada Era Modern}

Berdasarkan sejarah perkembanga komunitas nelayan yang mendiami wilayah pesisir di Sulawesi selatan pada pada umumnya mengalami proses perubahan kearah yang lebih maju dan kompleks. Perubahan yang relative cepat terseebut, terjadi setelah memasuki abad ke 20 yang di tandai oleh penerapan teknologi moderen dan berkembangnya pasar. (Ahmadin, 2017)

Para pelaut pengrajin perahu tradisional secara terus menerus mengubah, mengembangkan teknologi tradisional mereka dengan mengikuti setiap teladan 
baru yang dapat berbentuk tipe perahu yang lebih efesien, teknik-teknik yang lebih gampang digunakan, atau bahan yang lebih tahan sehingga pelayaran dan pembuatan perahu rakyat sampai kini masih eksis. (Heather Suterland, 2004)

Peningkatan teknologi penangkapan ikan menjadi suatu keharusan dalam upaya pemanfaatan potensi perikanan secara maksimal. Perkembangan setiap daerah pun berbeda dikarenakan ada peralatan yang disuatu daerah yang dikenal disuatu daerah tetapi tidak dikenal di daerah lain yang sudah menggunakan teknologi dalam alat tangkap ikan ada pula yang masih sederhana.

Perahu menggunakan mesin di ponrang ini pada tahun 1980an, sebenarnya karena pabbagang atau masyarakat yang ada disini sering ke kota palopo di daerah tanjung ringgit disana tahun 1980an itu sudah banyak mengenakan perahu motor disitulah masyarakat pabbagang desa ponrang juga mulai mengembangkan atau mulai memakai perahu bermotor. (Syukri, 2018)

Pabbagang desa ponrang sudah mengenal perahu motor pada sekitar tahun 1980an, ketika perahu-perahu tradisional berpapasan dengan perahu motor nelayan daerah lain. (saenal, 2018)

Mayarakat Pabbagang Ponrang sebelum mereka menggunakan mesin moderen di alat tangkap yang mereka gunakan seharihari, pabbagang selalu ke daerah pelabuhan tanjung ringgit untuk melihat temanya yang mencari ikan atau menetap mencari ikan di daerah pelabuhan tanjung ringgit, dan kemudian pabbagang desa ponrang mulai menirukan alat tangkap yang sudah moderen.

Bagang modern ini sendiri sudah banyak yang menggunkanya di ponrang pada tahun 2000 sama halnya seperti perahu bermotor masyarakat ponrang meihat bagang moderen itu di palopo, tepatnya di pelabuhan tanjung ringgit dulu, sangat beda dengan bagang apung bagang ini sudah banyak memiiki mesin-mesin seperti nyamar 30 tap,1 buah nyamar 30tap 1 buah,dynamo strong 205 wat, jaringnya juga lebar 33rb meter, tali kapal untuk menahan jangkar, modal biasa 1 bagang modern ini sekiran 1M. (Mancu, 2018)

Bagang Rambo yang digunakan oleh Pabbagang Desa Ponrang yang menjadi alat utama para pabbagang Desa Ponrang juga mengalami dampak moderisasi yang sudah menggunakan mesin yang mempunyai alat untuk menggerakan jaring bagan, dan bagan moderen itu ukuranya sangat besar. Tetapi bagang ini mulai banyak atau populasinya meningkat pada tahun 2000an dan Bagang ini biasanya disebut kalangan Masyarakat Desa Ponrang yaitu Bagang Rambo, Bagang Rambo ini sendiri mempunyai perbedaan yang sangat signifikan karena bagang ini sendiri sudah memakai alat alat yang moderen sehinggah mempermudah Pabbagang dalam proses penangkapan ikan sendiri, menurut keterangan narasumber diatas harga 1 Unit Bagang Rambo sekitaran 1 Milyar bahkan lebih. (sugianto, 2018)

Menurut keterangan diatas Bagang rambo moderen sehingga Proses penangkapan ikan di bagang Rambo ada beberapa hal yang sama dengan bagang tancap dan ada juga beberapa prosesnya berbeda. jika di bagang tancap semua serba manual atau mengandakan tenaga Pabbagang sendiri mengangkat jaring pake tenaga sendiri kalau di bagang Rambo ada mesin yang mengangkat sendiri jaringnya tapi sama di bagang tancap dia kalau mau di angkat ikanya pake tenaga tapi kalau bagang Rambo lebih jauh area penangkapanya karena berpindah-pindahmi dan perahunya pake mesin mi juga kalau kalau adami ikan bisa mi di isikan ke gabus bisami dibawa ke pelabuhan. (Nasir, 2018)

Sama halnya pada masa alat tangkap tradisional dimana kegiatan penangkapan ikan pada masa ketika alat tangkap sudah modern, pabbagang melakukan aktifitas menangkap ikan sama saja tetapi ada yang 
sedikit berbeda pabbagang mempersiapkan alat atau peralatan yang di butuhkan ketika ingin kelaut, mempersiapkan alat yang dibutuhkan dan mengecek mesin perahu dan membawa gabus atau keranjang yang biasanya sudah terisi es, es batu yang sudah di hancurkan di tempat lokasi perahu para nelayan diparkir atau di simpan disamping sungai yang biasanya di sebut masyarakat setempat adalah Pelabuhan Ponrang, tetapi es dibawa hanya ketika esok harinya akan membawa ikan atau masa panen sudah ingin dilakukan pada malam harinya.

Jika ingin mau ke laut dan menuju ke bagang Rambo biasanya berangkat sama teman-teman pukul 05.00 sore dan jarak tempuh itu biasa 2 jam perjalanan kalau anggota setiap Bagang Rambo 8 sampi 10 orang sudah termasuk pawang, kalau di bagang mi itu tidak semua pabbagang bisa pulang membawa ikan ke pelabuhan Ponrang, karena harus ada yang tinggal mejaga Bagang dan ikan, Tugasnya pawing itu sama ji dengan pabbagang lainya cuman dia punya baca-baca tersendiri seperti kalau baru mau jalan bagang supaya selamat ketika di laut dan memperingati para pabbagang lain tidak melakukan hal-hal yang dilarang seperti membuang Lombok ke laut dan berkata kasar menegur hal-hal yang aneh seperti bau-bau. (Nasir, 2018)

Kegiatan pabbagang ini dilakukan pada sore hari pukul 05.00 dan waktu tempuh kelokasi penangkapan ikan sekitar 2 jam bahkan jika lokasinya cukup jauh biasanya waktu yang dibutuhkan selama 3 jam. Sama halnya pada masa alat tangkap tradisional jumlah pabbagang dalam satu bagang mempunyai pawang dan anggotanya biasanya 8 sampai 10 pabbagang, dan tidak semua pabbagang dapat pulang ke rumah desa ponrang dalam waktu bersamaan,tetapi pabbagang tersebut, Lain hanya pawang, pawang harus tetap tinggal di bagang guna untuk menjaga bagang dan anggotanya agar tidak melakukan hal-hal yang tidak boleh dilakukan ketika dilaut seperti berbicaara tidak sopan, menegur bau yang aneh, tapi jika pawang tersebut ingin pulang maka pawang tersebut bergantian.

Pawang itu sendiri mempunyai tugas khusus dan selain itu membantu proses penangkapan ikan di bagang, yaitu pawang itu mempunyai baca-baca yang dibaca ketika bagang mulai beroprasi atau baru kelokasi penangkapan ikan, dan mengawasi para anggotanya agar tidak meakukan pelanggaran yang tidak boleh di lakukan ketika di laut.

Meskipun Alat tangkap lainya yang sudah moderen dan di pakai oleh para pabbagang desa ponrang tetapi alat penentu arah ketika di laut pabbgang desa ponrang masih menggunakan insting. Berbeda dengan Orang bugis dan indo melayu yang menggunakan petunjuk arah yang modern. Bugis dan indo melayu, penggunaan kompas magnet semakin meningkat dalam beberapa dekade terakhir dan menjadi alat penting bagi banyak nahkoda yang dilatih belakangan oleh pelaut bugis. (Gene Ammarell, 2016)

Masyarakat pabbagang desa Ponrang itu sendiri pada era moderen ini tidak menggunakan seperti alat penentu arah dikarenakan menurut informasi mereka sendiri tetapi hanya mengingat arah menuju ke bagang. Mengingat juga bagang yang merupakan alat tangkap utama Nelayan Desa Ponrang itu berpindah pindah tetapi berpindah ketempat yang mereka sering tempati untuk mencari ikan. pabbagang desa ponrang menentukan arah biasanya hanya dengan meihat keadaan alam sekitar seperti arah angin dan rasi bintang.

Bintang-bintang tak bernama dapat digunakan tanpa kompas dengan cara serupa dengan bintang-bintang dapat digunakan tanpa kompas dengan serupa bintang bernama, atau nahkoda dapat dengan mudah melihat mereka dalam malam hari ketimbang berulang-ulang menyalakan senter untuk menyalakan senter untuk memeriksa kompas sebuah 
contoh satu jenis bintang yang digunakan sendiri

\section{Sistem Bagi Hasil Oleh Pemilik Bagang ( modal ) dengan Pabbagang pekerja )}

\section{a. Pada Era Tradisional}

Sebelum membahas tentang sistem bagi hasil yang dilakukan pabbagang dengan pemilik bagang atau pemilik modal dari tahun 1970an, kembali mengingat nelayan Desa ponrang menurut informasi yang di dapatkan dari masyarakat setempat pappuka nama lain dari nelayan yang disebut masyarakat Desa Ponrang pada saat itu tidak menggunakan sistem bagi hasil.

Sistem bagi hasil dikalangan masyarakat nelayan, pada prinsipnya merupakan penilaian faktor-faktor produksi yang digunakan dalam usaha penangkapan ikan. Elemen dari faktor produksi yang dimaksud dalam konteks modal (biaya oprasioanal), punggawa atau pemimpin kegiatan menangkap ikan, sawi (pekerja/buruh). Komponen yang perhitungkan dalam sistem bagi hasil pada kelompok nelayan di padang adalah modal (biaya operasiona), alat (Perahu/mesin) dan (punggawa/sawi). (Ahmadin, 2009)

Rata-rata bagang yang ada di laut itu bukan milik pabbagang, tetapi para pabbagang hanya mencari ikan di bagang milik orang lain, tapi bagang yang ada di laut itu juga pemiliknya juga orang disini salah satu orang yang ada Desa Ponrang, bahkan pabbagang yang mencari ikan dibagang milik keluarganya sendiri. (samsuddin, 2018) Pabbagang Desa Ponrang sendiri ratarata bukan pemilik bagang tetapi mereka mencari ikan di bagang orang lain bahkan tak jarang bagang yang di tempati mencari ikan adalah milik kerabat mereka sendiri, meskipun tak jarang pemilik bagang dan pabbagang merupakan kerabata tetapi sistem bagi hasil ini tetap di terapkan di kalangan pabbagang dan pemilik bagang desa ponrang, kalaupun ada beberapa pabbagang yang tidak memiliki hubungan keluarga dari pemilik bagan dipastikan adalah pabbagang lainya merupakan tetangga pemilik bagang.

Nelayan di kampung padang pada dekade 1970an mengenal istilah tesan seperti halnya pada petani penggarap kebun daerah pegunungan. Sistem tesan dalam konteks ini yakni kecendrungan para pemilik alat tangkap yang tergolong kondisi ekonomi maupun menyewakan peralatanya kepada nelayan lain yang tergolong miskin serta tidak mampu membeli alat tangkap. Sistem bagi hasil dari pola hubungan kerja nelayan semacam ini, yakni dilakukan dengan sistem bagi dua .bagi pemilik peralatan mendapat bagian dari 50 persen dari ikan hasi tangkapan, dan 50 persen yang lain adalah bagian para nelayan tersebut, tidak diberlakukanya adanya target yang harus dicapai oleh para pelaut (penangkap ikan). (Ahmadin, 2009)

Sedangkan sistem bagi hasil yang diterapkan pemilik Bagang dengan pabbagan dimana jika pemilik bagang dapat $50 \%$ maka setiap 1 pabbagang mendapatkan upah yang sama dengan pemilik bagang namun upah yang diberikan kepabbagang 1 bulan sekali atau 2 bulan sekali dan semua hasil tangkapan pabbagang yang didapat di berikan ke paccata apabila hanya mendapat satu kerancang ikan yang dibawah pulang itu tetap di setor kepaccata untukdijual dan uang hasil jualanya di simpan sampai 1 atau hampir 2 bulan (saenal, 2018)

Pabbagang Desa Ponrang sendiri pada tahun 1970 memiliki kesamaan oleh nelayan di kampung padang yang menerapkan sistem tesan, di Desa Ponrang juga menerapkan sistem yang sama dimana pemilik bagang menggaji pabbagang yang mencari ikan di bagang mereka, dan mereka memberi upah ke pemilik bagang. Berdasar keterangan yang didapatkan oleh pabagang yang berada di desa ponrang bahwa pemilik bagang mendapatkan $50 \%$ persen maka pabbagang juga akan mendapatkan upah yang sama dengan pemiik bagang. 


\section{b. Pada Era Moderen}

Pada era teknologi penangkapan ikan yang sudah modern bagi para nelayan ini mempermudah dari proses penangkapan ikan baik dari sarana transportasi untuk melaut dan proses ketika para nelayan mengoprasikan bagang yang sudah modern tanpa tenaga yang lebih.

Sistem bagi hasilnya sekarang masih sama bagi hasilnya jika bagang tanca dengan bagang Rambo sekarang antara pemilik bagang dan pabbagang dimana hasil tangkapan di jual oleh para pemilik bagang, saya dan teman pabbagang biasanya membawa ikan dari laut ke pelabuhan itu mulai jam 04.00, sampai ke pelabuhan biasanya pukul 06.30 atau pukul 07.00. (Saenal, 2018)

Tetapi sistem penjualan di era tradisional tidak mengalami perubahan yang berarti, sama halnya sistem bagi hasil di masa pabbagang tradisonal, sistem bagi hasil pada masa sekarang yang di lakukan pabbagang atau ketika pabbagang sudah menggunakan alat tangkap modern terkhusus aat tangkap bagang yang menjadi alat tangkap yang dari dulu pada tahun 1970an hingga skarang menjadi alat tangkap utama yang digunakan masyarakat pabbagang ponrang.

Sama halnya ketika sistem bagi hasil pabbagang tradisional dengan pabbagang modern, bukan anggota pabbagang ataupun pawang bagang yang melakukan aktifitas penjualan dari hasil tangkap mereka melainkan pemilik modal atau yang memiliki bagang ,jika para pabbagang sudah mencapai masa target pengoprasian bagan dilaut maka para pabbagang menyetor hasil tangkapan ikan mereka kepada pemilik bagang atau orang yang dipercayai menjual hasi tangkapan dari anggotannya, para pabbagang ponrang membawa hasil tangkapan mereka itu pada pagi hari sekitaran jam 05.30 dan biasanya air sungai yang menjadi sarana jalur penghubung masyarakat pabbagang ke laut,surut dan airnya mulai naik ketika pukul 07.00 pagi.

Perahu yang membawa ikan ke pelabuhan itu tidak bisa langsung ke palabuhan karena harus tunggu air sungai naik dulu, tapi bergantian itu perahu sandar ke pelabuhan karena hanya cukup 2 sampai 3 perahu yang bisa sandar dan para pabbagang menaikan kardus ikan atau keranjang ikan, hasil tangkapan pada alat tangkap modern bagang Rambo ini di banding dengan bagang tancap lebih banyak (saenal, 2018)

Menurut kererangan narasumber dan peneliti secara langsung melihat aktivitas di pagi hari para pabbagang membawa ikan ke pelabuhan Desa Ponrang, Perahu yang berukuran besar itu saling bergantian untuk menaikan kardus kardus ikan mereka maupun keranjang-keranjang ikan mereka ke pelabuhan bergantian dengan perahu pabbagang lainya selalu disebutkan oleh masyarakat Desa Ponrang yang menjadi tempat tiap hari tiap pagi di lakukan oleh masyarakat setempat sebagai sarana tempat jual beli ikan yang di dapat oleh para pabbagang. Di era alat tangkap modern ini hasil tangkapan semakin meningkat jadi hasil jualan ikan semakin tinggi dan disesuaikan dengan harga pemasaran ikan pada umumnya.

Ikan yang mahal disini itu 1 keranjang ikan lado biasa sampae Rp.900.000,- jika kualitasnya bagus dan ukuranya besar biasanya sampai Rp.1.000.000 sedangkan ikan mairo Rp.350.000,- (Nadira, 2018)

Jika ikan yang di dapatkan ikan yang kualitas bagus biasanya pemilik bagang atau pencatat hasil tangkapan ikan dijual dengan harga yang berfariasi kadang harga ikan sekitar dijual sebesar di jual dengan harga Rp.900.000,- dan menurut data yang saya dapat ketika harga ikan mengalami kenaikan biasanya hargan ikan perkardus mencapai harga Rp.1.000.000 sedangkan biasanya jenis ikan seperti ikan mairo sekardus itu seharga Rp.350.000,- dan 
harganya naik ketika harga ikan dipasaran naik.

Pemilik bagang mengumpukan hasil jualan ikan yang di dapatkan oleh pabbagang itu selama 2 bulan, lalu di bagi rata oleh pemilik bagang, dan pada era dimana alat tangkap sudah modern mengalami peningkatan, jika bagang modern biasanya Rp.10.000.000 sekarang sudah bisa mendapatkan 40juta satu kali panen dalam1 unit bagang bahkan lebih.

Pembeli ikan sering di Mamanya wawang dan bapaknya wulan berfariasi ikan yang saya beli 1 sampai 2 dan paling banyak samapi 4 gabus ikan, dan harga ikan berfariasi harganya dan tergantung jenis ikannya kalau ikan mairo bisa satu keranjang 350rb kalau ikan layang 1 kerangjang biasanya 600rb sedangkan kalau 1 Gabus itu biasa hampir 1 juta seperti jenis ikan putih apalagi jika kondisi ikan sangat segar (agustono, 2018)

Pembeli dominan membeli ikan di pelabuhan ponrang itu sendiri adalah masyarakat setempat dan masyarakat tetangga Desa Ponrang seperti dari Desa Mario, Desa Lumi, teta pappalele yang sangat berpengaruh pappalele membeli ikan dari paccata dengan jumlah yang lumayan banyak paling sedikit itu satu kardus atau satu keranjang dan paling banyak bisa membeli 4 Gabus. Desa Ponrang sendiri melakukan aktifitas jual menjual, beli membeli dan kegiatan ini berlangsung setiap hari di pagi hari dan selalu saja ramai akan pembel

\section{Kesimpulan}

Adapun kesimpulan yang dapat di dapatkan dari pembahsan diatas adalah Masyarakat desa Ponrang rata-rata penduduknya menggeluti profesi sebagai nelayan namun di Desa Ponrang sendiri bukan merupakan daerah pesisir dan alat tangkap yang digunakan untuk mencari ikan di masyarakat pabbagang ponrang adalah bagang dari era tradisional sampai era modern atau pada saat mengalami perkembangan perkembangan dimana bagang yang digunakan pada era tradisional adalah bagang tancap sedangkan bagang yang digunakan ketik menggunakan bagang rambo, adapun yang pertama kali memiliki pertama Bagang modern Desa Ponrang adalah Ambe ambarang dan yang memiliki bagang moderen pertama kalinya di Desa Ponrang $\mathrm{Hj}$.Marsuki dan adapun sistem bagi hasil yang diterapkan adalah sistem tesan.

\section{DAFTAR PUSTAKA}

Agusabdurrahman, 2008. Model Kebijakan Pemberdayaan Nelayan Bantul dari perspektif Ekonomi dan Hukum. jurnal fenomena, Volume 6, p. 6.

Agustono, 2018. Harga Ikan Perkardus [Interview] (sunday april 2018).

Ahmadin, 2009. Ketika lautku tak berikan lagi. makassar: Rayhan intermedia.

Ahmadin, 2017. Nelayan Tradisional dan Moderen. Makassar: Rayhan Intermedia.

BPS, 2016. Badan Pusat Statistik. Luwu: s.n. Gene Ammarell, 2016. navigasi bugis. makassar: inninawa.

H.Nani, 2018. Pembagian Upah Antara Pemilik Bagang dengan Pabbagang [Interview] (thuesday april 2018).

Heather Suterland, 2004. Konstitunitas dan perubahan dalam sejarah sulawesi. Yogyakarta: Ombak.

Helius Sjamsuddin, 2012. Metodoogi Sejarah. Yogyakarta: Ombak.

Hj.Marsuki, 2018. Pemilik Bagang Rambo Pertama Kali di Desa Ponrang [Interview] (Saturday july 2018).

Hj.Nani, 2018. [Interview] (tuesday april 2018).

Hj.Nani, 2018. Pemberian Upah ke Pabbagang [Interview] (tuesday april 2018). 
Kusnadi, 2004. Polemik Kemiskinan nelayan. Bantul: Pustaka jogja mandiri.

Mancu, 2018. Keberadaan Bagang Rambo di Desa Ponrang [Interview] (thursday febuari 2018).

Nadira, 2018. Harga Ikan Perkardus [Interview] (sunday april 2018).

Nasir, 2018. Jumah Pabbagang dan Pawang di Bagang Rambo [Interview] (Saturday April 2018).

Nasir, 2018. Proses Penangkapan Ikan di Bagang Rambo [Interview] (Saturday April 2018).

Pida, 2018. Waktu Keberangkatan Pabbagang ke Bagang [Interview] (wednesday Febuari 2018).

Saenal, 2018. Pristiwa Korban Meninggal Dunia di Bagang [Interview] (Westerday April 2018).

Saenal, 2018. Proses menaikan Karduskardus Ikan ke Pelabuhan [Interview] (sunday april 2018).

Saenal, 2018. Sistem Bagi Hasil oleh Pemilik Bagang dengan Pabbagang [Interview] (Thuesday April 2018).
Samsuddin, 2018. Kepemilikan Bagang [Interview] (thursday febuari 2018).

Samsuddin, 2018. Wilayah Desa Ponrang [Interview] (wednesday Febuari 2018).

Singgih Tri Suistiyono, 2004. Sejarah maritim Indonesia. Makassar: Program Hibah Penulisan buku.

Suhara, H., 2018. Awal Mula Adanya Bagang dan Pabbagng di Desa Ponrang [Interview] (wednsday febuari 2018).

Syamsu Bahri, 2014. Alat tangkap neayan tradisional. Makassar: Pustaka Sawerigading.

Syamsu Bahri, 2014. Alat tangkap nelayan tradisional. Makassar: Pustaka Sawerigading.

Syukri, 2018. Perahu yang Sudah menggunakan Mesin di Desa Ponrang [Interview] (Saturday April 2018). 